Open Access

\title{
The heart of a dragon: 3D anatomical reconstruction of the 'scaly-foot gastropod' (Mollusca: Gastropoda: Neomphalina) reveals its extraordinary circulatory system
}

Chong Chen ${ }^{1 *}$, Jonathan T. Copley ${ }^{2}$, Katrin Linse ${ }^{3}$, Alex D. Rogers ${ }^{1}$ and Julia D. Sigwart ${ }^{4}$

\begin{abstract}
Introduction: The 'scaly-foot gastropod' (Chrysomallon squamiferum Chen et al., 2015) from deep-sea hydrothermal vent ecosystems of the Indian Ocean is an active mobile gastropod occurring in locally high densities, and it is distinctive for the dermal scales covering the exterior surface of its foot. These iron-sulfide coated sclerites, and its nutritional dependence on endosymbiotic bacteria, are both noted as adaptations to the extreme environment in the flow of hydrogen sulfide. We present evidence for other adaptations of the 'scaly-foot gastropod' to life in an extreme environment, investigated through dissection and 3D tomographic reconstruction of the internal anatomy.

Results: Our anatomical investigations of juvenile and adult specimens reveal a large unganglionated nervous system, a simple and reduced digestive system, and that the animal is a simultaneous hermaphrodite. We show that Chrysomallon squamiferum relies on endosymbiotic bacteria throughout post-larval life. Of particular interest is the circulatory system: Chrysomallon has a very large ctenidium supported by extensive blood sinuses filled with haemocoel. The ctenidium provides oxygen for the host but the circulatory system is enlarged beyond the scope of other similar vent gastropods. At the posterior of the ctenidium is a remarkably large and well-developed heart. Based on the volume of the auricle and ventricle, the heart complex represents approximately $4 \%$ of the body volume. This proportionally giant heart primarily sucks blood through the ctenidium and supplies the highly vascularised oesophageal gland. Thus we infer the elaborate cardiovascular system most likely evolved to oxygenate the endosymbionts in an oxygen poor environment and/or to supply hydrogen sulfide to the endosymbionts.

Conclusions: This study exemplifies how understanding the autecology of an organism can be enhanced by detailed investigation of internal anatomy. This gastropod is a large and active species that is abundant in its hydrothermal vent field ecosystem. Yet all of its remarkable features-protective dermal sclerites, circulatory system, high fecundity_can be viewed as adaptations beneficial to its endosymbiont microbes. We interpret these results to show that, as a result of specialisation to resolve energetic needs in an extreme chemosynthetic environment, this dramatic dragon-like species has become a carrying vessel for its bacteria.
\end{abstract}

Keywords: 'Scaly-foot gastropod', Chrysomallon squamiferum, Morphology, Hydrothermal vents, Anatomy, Deep-sea, Adaptation, Neomphalina

\footnotetext{
* Correspondence: chong.chen@zoo.ox.ac.uk

'Department of Zoology, University of Oxford, The Tinbergen Building, South

Parks Road, Oxford OX1 3PS, UK

Full list of author information is available at the end of the article
} 


\section{Introduction}

Deep-sea hydrothermal vents represent a challenging environment where organisms face 'extreme' conditions such as hypoxia, very acidic water, and the presence of toxic materials such as hydrogen sulfide and heavy metals $[1,2]$. Despite this, hydrothermal vents host a high biomass, comparable to that of tropical coral reefs (Van Dover, 2000). Vent ecosystems are supported by chemosynthetic primary production carried out by bacteria that oxidise reduced compounds such as hydrogen sulfide and methane to produce energy for fixing carbon dioxide or other carbon compounds into organic matter [3].

Animals flourishing in vents often have anatomical adaptations to the unusual environment. Many species host epibiotic microbes that they feed on for nutrition, for instance the vent shrimp Rimicaris exoculata Williams \& Rona, 1986 houses both sulfur-oxidizing and methanotrophic bacteria in the gill chamber [4] and the galatheid squat lobster Shinkaia crosnieri Baba \& Williams, 1998 farms bacteria on dense setae on the ventral face of the carapace [5]. Some species further house chemosynthetic bacteria internally as endosymbionts. The giant tube worm Riftia pachyptila Jones, 1981 is known to host thioautotrophic (sulfur-oxidizing) endosymbionts in a specialised organ, the trophosome; and has a vestigial digestive system [6]. Similarly, vesicomyid clams house endosymbionts in the gill and also have a much reduced digestive tract [7]. Some species are able to combine multiple feeding strategies, for example Bathymodiolus thermophilus Kenk \& Wilson, 1985 is capable of filter-feeding while also hosting endosymbionts in the gill [8]. Other anatomical adaptations to thrive in chemosynthetic environments are also known. Many vent polychaetes have increased gill surface area to facilitate effective oxygen extraction, as well as high oxygen affinity haemoglobins and haemocyanins $[9,10]$.

The 'scaly-foot gastropod', Chrysomallon squamiferum Chen et al., 2015 [11], is distinctive among hydrothermalvent molluscs for its numerous dermal sclerites, which are often mineralised with iron sulfide. This species inhabits the hydrothermal vent fields of the Indian Ocean, on the walls of black-smoker chimneys or directly on diffuse flow sites. First discovered in the Kairei hydrothermal vent field, Central Indian Ridge (CIR) [12], it has also been found in two more vent fields: Solitaire field, CIR (Nakamura et al., 2012) and Longqi field (literally meaning 'dragon flag' in Chinese, and also known as Dragon field, [13, 14]), Southwest Indian Ridge (SWIR) [13, 15, 16]. Both morphological and genetic characters place C. squamiferum in Peltospiridae, a family restricted to hydrothermal vent ecosystems in the clade Neomphalina [17]. Chrysomallon squamiferum reaches $45 \mathrm{~mm}$ in shell length, much larger than the other members of the family which are generally small ( $<15 \mathrm{~mm}$ in shell length).
The unusual external morphology of Chrysomallon has been described by a number of studies [17-19] with the surface mineralogy investigated in detail [20,21], and a number of studies have concentrated on its unique way of housing endosymbionts in the oesophageal gland [22, 23], instead of the gill, like other vent gastropods such as Alviniconcha spp. [24]. The internal anatomy of several peltospirid genera have been investigated previously (mainly Rhynchopelta concentrica McLean, 1989 but also Peltospira, Nodopelta, Echinopelta and Hirtopelta [25]; as well as Pachydermia laevis Warén \& Bouchet, 1989 [26]), and C. squamiferum is known to differ from these, particularly in its acquisition of endosymbionts and gigantism relative to other peltospirids $[17,22]$. The only previous description of the internal anatomy of the 'scaly-foot gastropod' is a short supplementary text [17]. The aim of the present study was to investigate this unusual species to examine possible further anatomical adaptations to life in the vent environment.

\section{Results}

The overall anatomical plan of Chrysomallon squamiferum conforms to that of other Neomphalina (Figs. 1, 2). This include non-papillate tentacles, single left bipectinate ctenidium, single auricle, rhiphidoglossate radula with a single pair of radular cartilages, a rectum that does not penetrate the heart but passes ventral to it, and statocyst with a single statolith (Figs. 3, 4, 5; [27]). A number of histological characters can also be compared to other members of Neomphalina (Fig. 6). The basic organ anatomy in adult specimens was previously described by

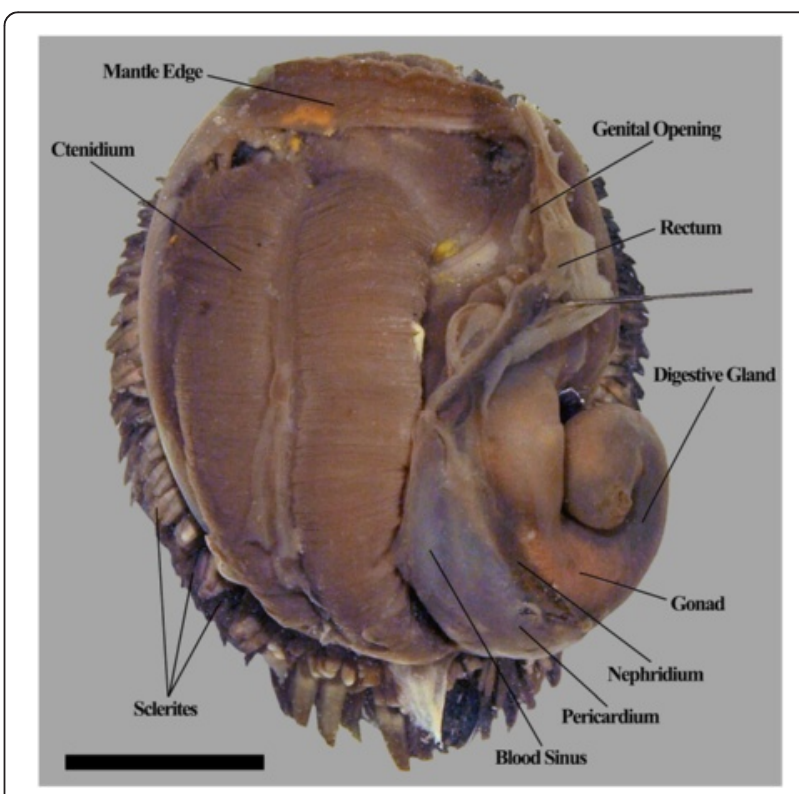

Fig. 1 The 'scaly-foot gastropod', Chrysomallon squamiferum, mantle cavity overview (shell and mantle tissue removed). Scale bar: $1 \mathrm{~cm}$ 


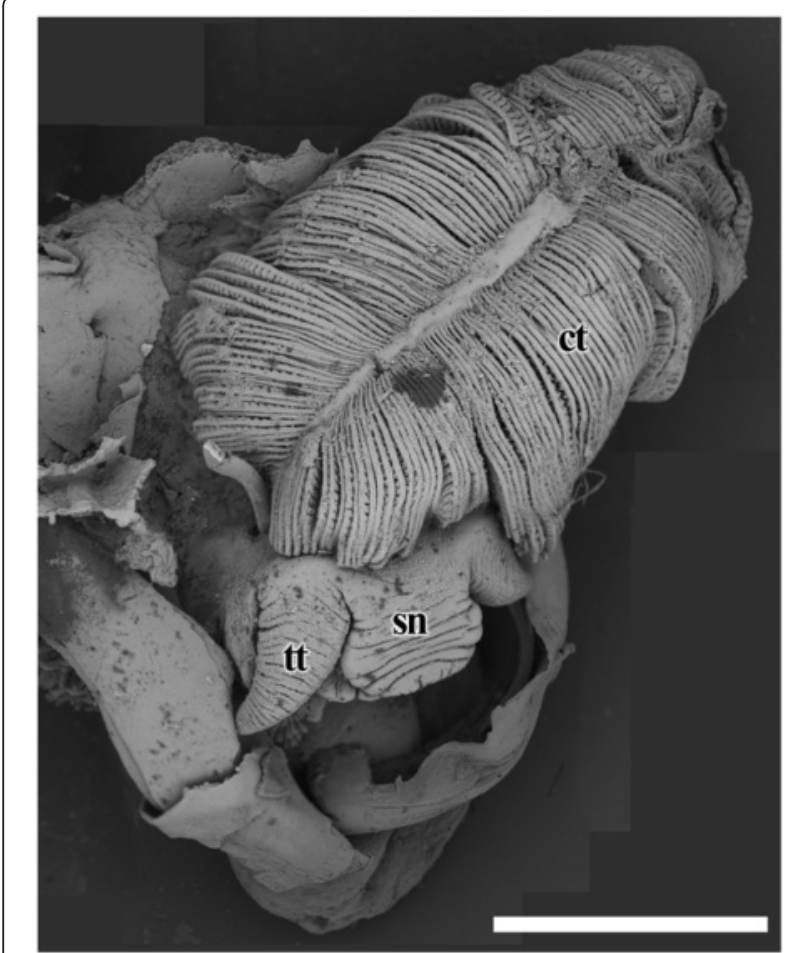

Fig. 2 Structural details of the head and ctenidium of Chrysomallon squamiferum, composite of 22 scanning electron micrographs of a freeze-dried juvenile specimen. Abbreviations: ct, ctenidium; sn, snout; $\mathrm{tt}$, cephalic tentacle. Scale bar: $2 \mathrm{~mm}$

Warén et al. [17] but our dissections expand considerably on that report (Fig. 7).

\section{External Morphology}

Chrysomallon squamiferum is a loosely coiled snail with the soft parts occupying approximately two whorls (Figs. 1, 3a). The snout is thick and tapers distally to a blunt end, the mouth is a circular ring of muscles when contracted and closed. Two smooth cephalic tentacles are present, these are thick at base and gradually tapers to a fine point at the distal tips (Fig. 2). There are no eyes. Specialised copulatory appendages are lacking in the anterior head-foot region. There is no pedal gland in the propodium. The epipodium does not carry any epipodial tentacles but is instead densely covered in hard sclerites, imbricating in a roof-tile manner. An operculum is present at the metapodium, exposed and well-sized in juveniles (Additional file 1: Fig. 1) but the relative size decreases as individuals grow. In adults the operculum is elongate and clearly distinct but buried under layers of sclerites ([19]: fig. 2). The shell muscle is horse-shoe shaped and large, divided in two parts on the left and right, connected by a narrower attachment. The mantle edge is thick but simple without distinct features. The mantle cavity of $C$. squamiferum is deep and reaches the posterior edge of the shell. The medial to left side of the cavity is dominated by a very large bipectinate ctenidium (Figs. 1, 2, 3a). Ventral to the visceral mass the body cavity is occupied by a huge oesophageal gland extended to fill the ventral floor of the mantle cavity (Fig. 4c).

\section{Digestive and Excretory System}

The mouth opening on the ventral side of snout leads to buccal cavity contains a rhipidoglossate radula (Fig. 5a). The epithelium of the inner lip is composed of a columnar epithelium with a thin cuticle (Fig. 6a). There are no jaws. We found no discrete salivary glands. The radula ribbon is long, width to length ratio is approximately 1:10 in the serially sectioned specimen (Figs. 3c, 5b; structural details shown by Warén et al. [17]: fig. S2A). A single pair of prominent radula cartilages support the anterior radula ribbon. The two cartilages are in contact at their anterior extent and become separate ventrally (Fig. 5f). At the posterior end of the cartilage pair the radula ribbon folds under and emerges from the growing radular sac below the buccal mass. A part of the anterior oesophagus rapidly expands into a huge hypertrophied blind-ended oesophageal gland (Fig. 5a) which occupies much of the ventral face of the mantle cavity (estimated $9.3 \%$ body volume). The dorsal fold of the oesophagus (Fig. 6b) may represent an extensive food groove but we cannot exclude the possibility this shape is due to an artefact of tissue distortion during fixation. The oesophageal gland has a uniform texture (Fig. 6c) and is highly vascularised with fine blood vessels (Fig. 7b).

The digestive system apart from the oesophageal gland is relatively small and forms a simple loop (Fig. 5b). The midgut is forms a clearly discernable stomach as a distinctly widened and enlarged region separating it from the foregut and hindgut (Fig. 5b). There is no gastric shield nor style; the stomach wall is ciliated but we could not identify a discrete sorting area. The stomach has at least three ducts at its anterior right connecting to the digestive gland; the extensive and unconsolidated digestive gland extends to the posterior filling the shell apex (Fig. 2d, 2f). The nephridium is central, tending to the right side of the body (Figs. 1, 5b), as a thin dark layer of glandular tissue (Fig. 7e). It is anterior and ventral of the digestive gland and in contact with the dorsal aspect of the foregut (Fig. 5a).

The posterior aspect of the oesophagus passes directly above the oesophageal gland and ventral of the auricle to reach the ventral face of the visceral mass (Fig. 5a). The digestive system runs directly from anterior to posterior in contact with the dorsal aspect of the oesophageal gland, and the nephridium (immediately posterior to the oesophageal gland); it widens into a distinct stomach embedded within the digestive gland. The posterior intestine emerges from the left anterior side of the stomach, runs anteriorly and curving to the right into the oesophageal 


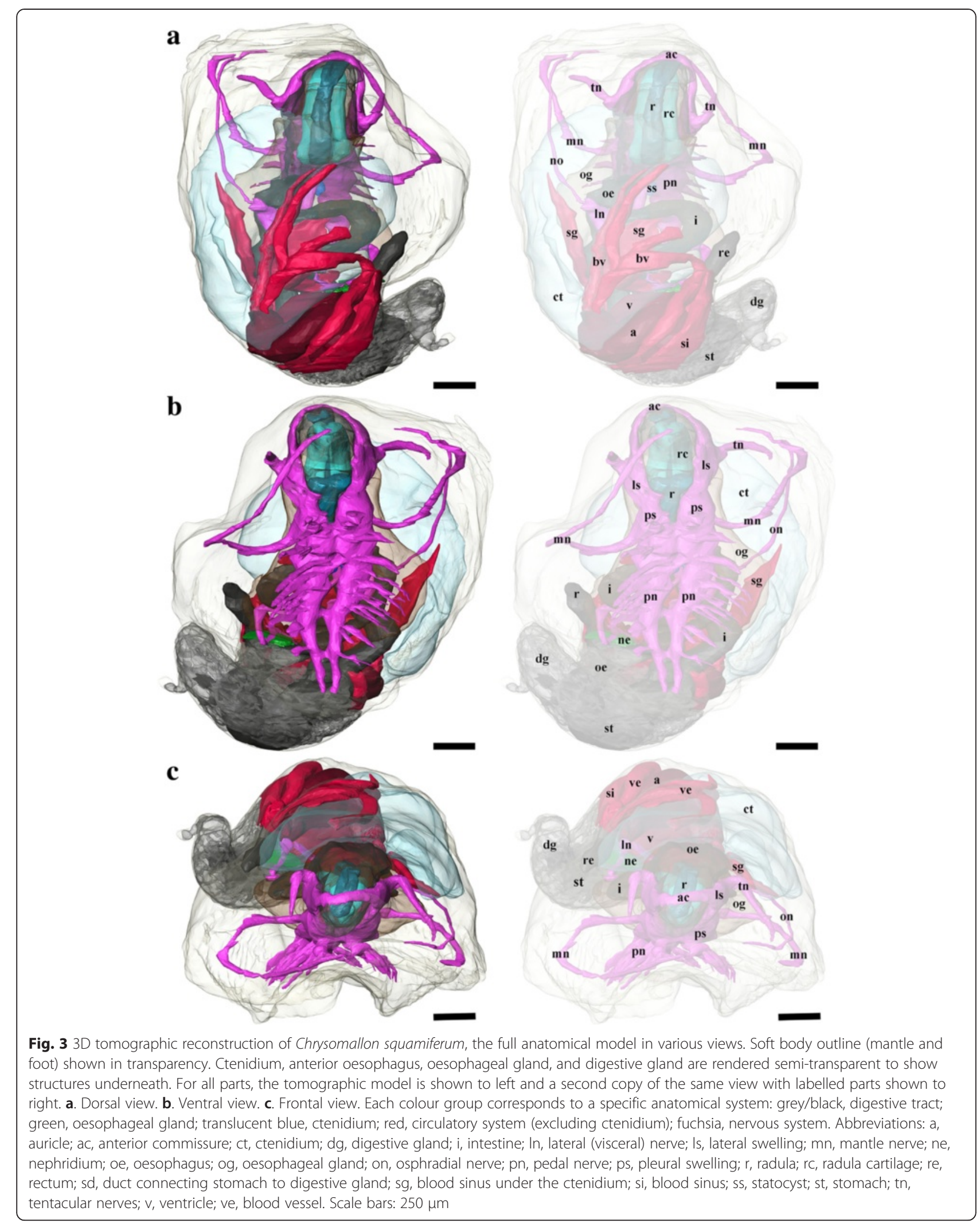



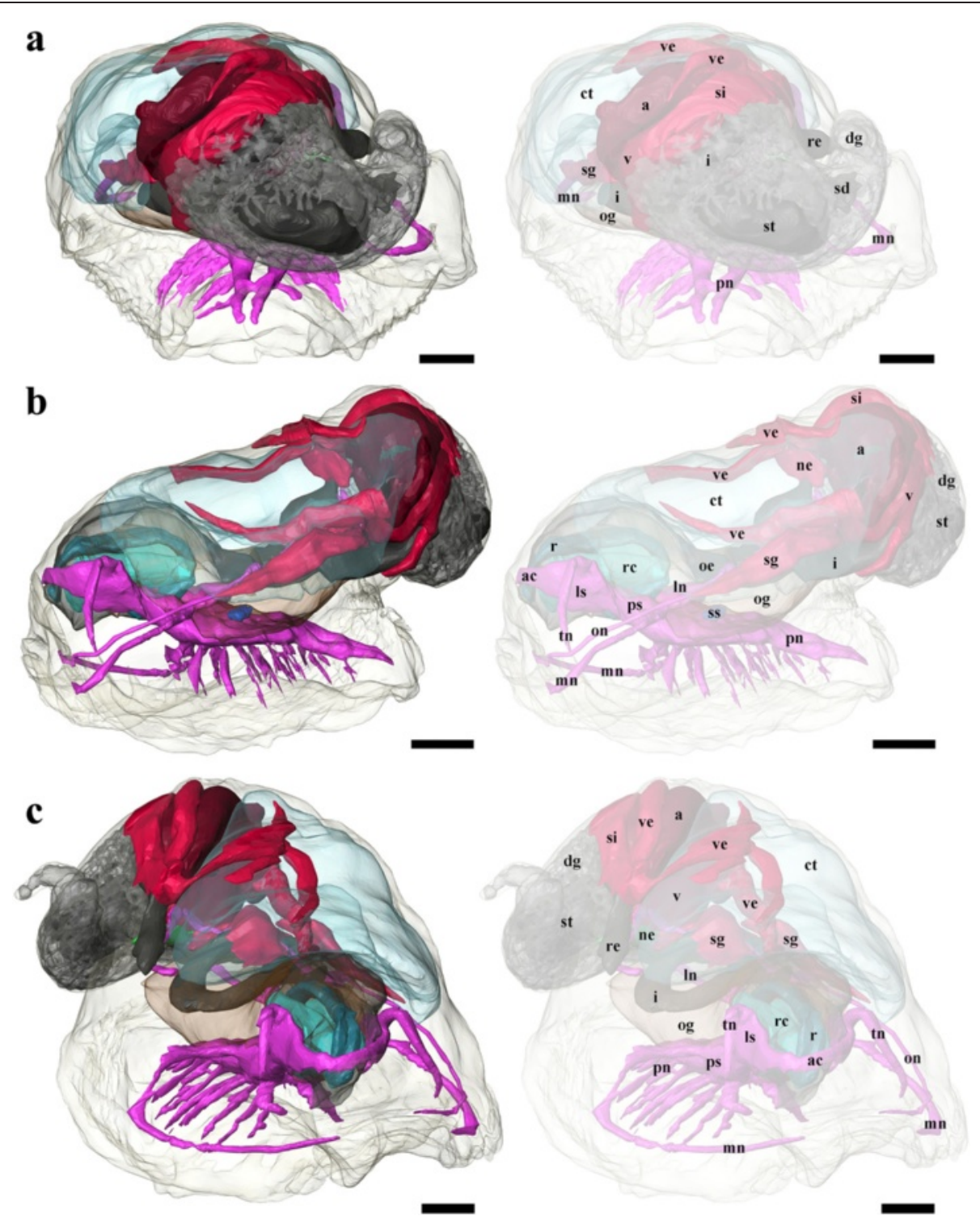

Fig. 4 3D tomographic reconstruction of Chrysomallon squamiferum, the full anatomical model in various views (continued). Soft body outline (mantle and foot) shown in transparency. Ctenidium, anterior oesophagus, oesophageal gland, and digestive gland are rendered semi-transparent to show structures underneath. For all parts, the tomographic model is shown to left and a second copy of the same view with labelled parts shown to right. a. Rear view. b. Left view. c. Angled (right side) view. Each colour group corresponds to a specific anatomical system: grey/black, digestive tract; green, oesophageal gland; translucent blue, ctenidium; red, circulatory system (excluding ctenidium); fuchsia, nervous system. Abbreviations: a, auricle; ac, anterior commissure; ct, ctenidium; dg, digestive gland; i, intestine; In, lateral (visceral) nerve; Is, lateral swelling; mn, mantle nerve; ne, nephridium; oe, oesophagus; og, oesophageal gland; on, osphradial nerve; pn, pedal nerve; ps, pleural swelling; r, radula; rc, radula cartilage; re, rectum; sd, duct connecting stomach to digestive gland; sg, blood sinus under the ctenidium; si, blood sinus; ss, statocyst; st, stomach; tn, tentacular nerves; v, ventricle; ve, blood vessel. Scale bars: $250 \mu \mathrm{m}$

gland and the next turn of the digestive tract is completely embedded within the oesophageal gland. It then returns out of the oesophageal gland to the left, crossing dorsally over the oesophagus, runs posteriorly to contact the digestive gland dorsal of the stomach, and then turns anteriorly down the right mantle wall to exit the mantle cavity on the right, as the rectum (Figs. 3a, $7 \mathrm{~g}$ ). The anus opening is also located on right side of animal, close to the transverse mid-line of the gastropod, above the genital slit (Fig. 1). The intestine throughout is simple in cross section and does not have a typhosole.

The hindgut was typically filled with consolidated pellets of chalky unidentified material, only present in stomach and posterior to it, and seen in specimens of all 


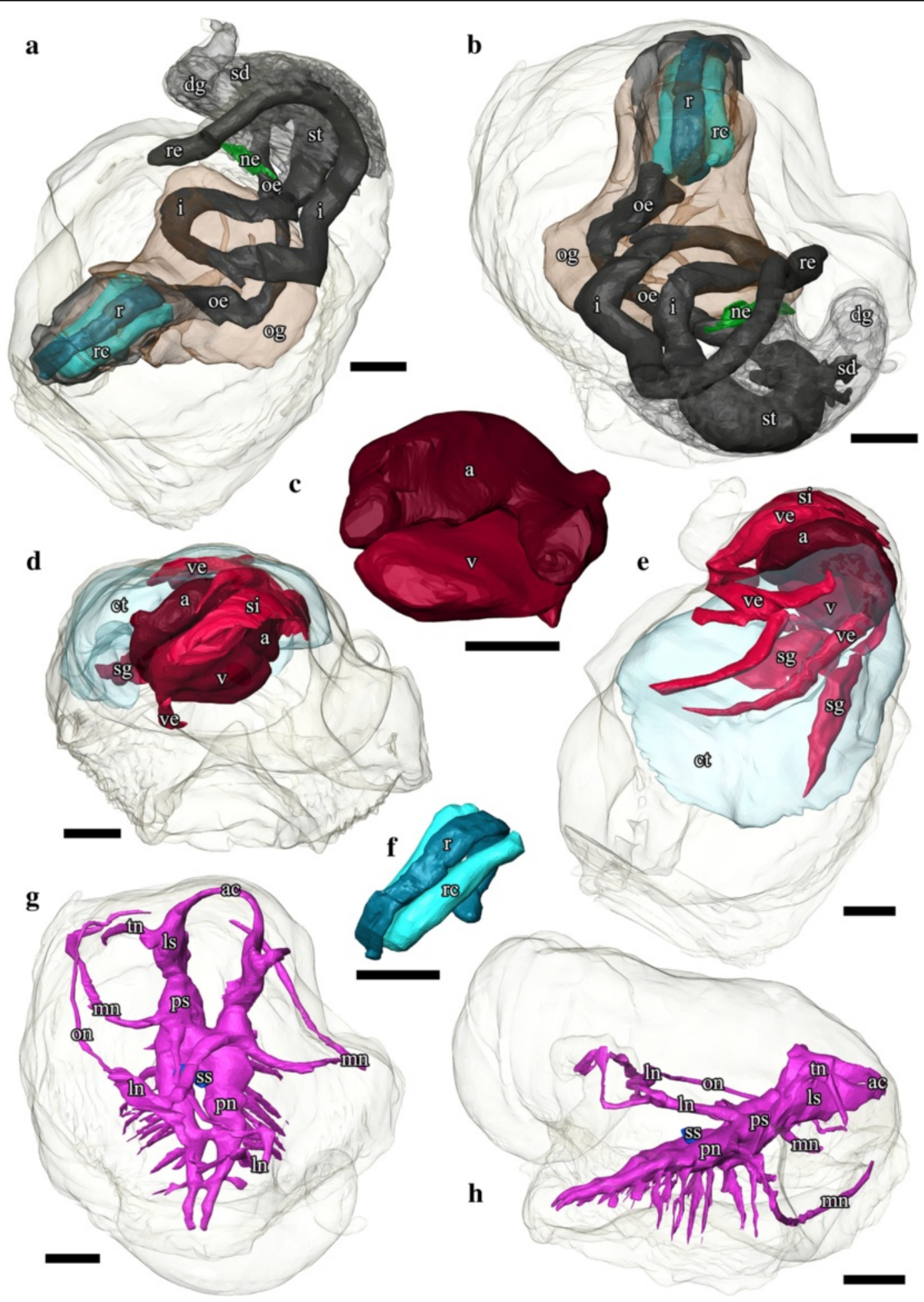

Fig. 5 3D tomographic reconstruction of Chrysomallon squamiferum. Soft body outline shown in transparency. Ctenidium, anterior oesophagus, oesophageal gland, and digestive gland are rendered semi-transparent to show structures underneath. $\mathbf{a}-\mathbf{b}$. Digestive and excretory systems. $\mathbf{c}$ Heart. d-e. Circulatory system. f. Radula and radula cartilage. g-h. Nervous system. Abbreviations: a, auricle; ac, anterior commissure; ct, ctenidium; $\mathrm{dg}$, digestive gland; i, intestine; In, lateral (visceral) nerve; Is, lateral swelling; mn, mantle nerve; ne, nephridium; oe, oesophagus; og, oesophageal gland; on, osphradial nerve; pn, pedal nerve; ps, pleural swelling; r, radula; rc, radula cartilage; re, rectum; sd, duct connecting stomach to digestive gland; sg, blood sinus under the ctenidium; si, blood sinus; ss, statocyst; st, stomach; tn, tentacular nerves; v, ventricle; ve, blood vessel. Scale bars: $250 \mu \mathrm{m}$ 


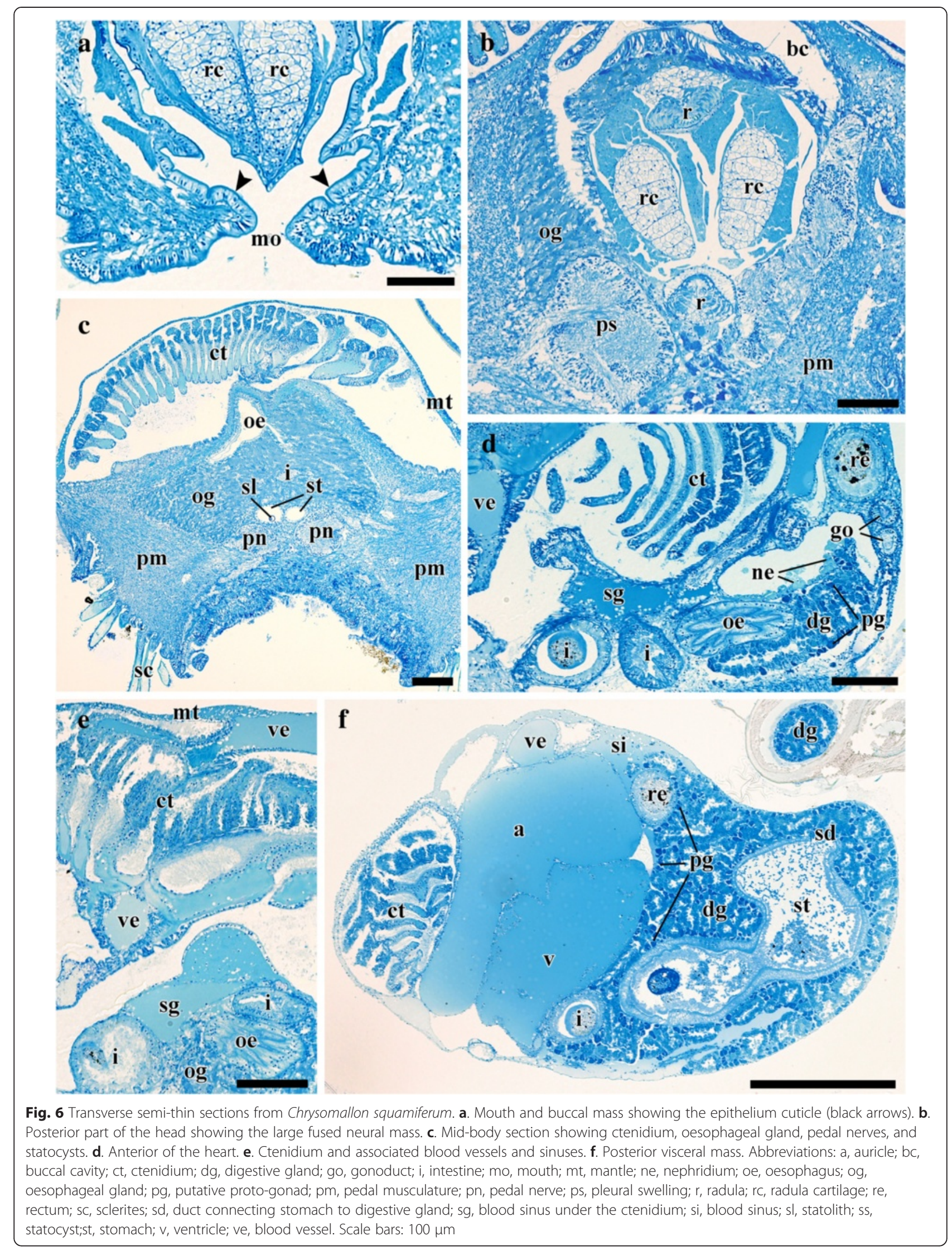


sizes (Figs. 6f, 7b). These are possibly sulphur granules produced by the endosymbiont and represent a way for detoxing hydrogen sulfide.

\section{Circulatory System}

The single large ctenidium (Figs. 1, 5e) occupying $15.5 \%$ of the body volume in the serially sectioned specimen), it reaches the posterior end of the mantle cavity and further curls to enter the visceral mass. It is densely packed with thin gill filaments on both sides (Figs. 2, 6c) and apparently without skeletal rods. There are two prominent semi-enclosed blood sinuses under the gill $(0.7 \%$ body volume), which fill the concavity formed by the ventral aspect of the gill filaments (Figs. 5e, 6e, 7c). To the posterior right of the ctenidium lies a hypertrophied auricle (Figs. 5c, 6f). A ventricle of even larger size lies directly ventral of the auricle (Fig. 7a). A simple pericardium is present (not illustrated) and encloses the heart with tissue connected to the dorsal mantle. The ventricle has thick muscular walls with many crossing muscle bundles (Fig. 7d). The auricle and ventricle together occupy $4 \%$ of the body volume (Figs. $5 \mathrm{~d}, 6 \mathrm{f}$ ). Diagonally above the right half of the auricle is a prominent blood sinus directly connected to the auricle ( $0.8 \%$ body volume), it begins anteriorly before the anterior end of the auricle and extends posteriorly to reach posterior end of the ventricle (Fig. 5c). Thick blood vessels are clear above and below the ctenidium (Fig. 5e). In adult specimens several blood sinuses are located in the posterior half of the mantle cavity but the location and extent differed between individuals. Some of these blood sinuses are connected to the mantle tissue but other large areas of haemocoel, jellylike and with a pale bluegrey colour in preserved specimens, are found covering the gonad and throughout the body (Fig. 1). The oesophageal gland is highly vascularised with smaller blood sinuses and a dense network of fine blood vessels (Fig. 7b).

\section{Nervous System and Sensory Structures}

The nervous system is voluminous (Figs. 5g, 5h; occupying approximately $5.7 \%$ of body volume in the serially sectioned juvenile specimen, although proportionately much smaller in adults). The brain is a more or less solid neural mass without clear structure or ganglia, and there are no eyes or other cephalic sensory structures. As typical of gastropods the nervous system is composed of an anterior oesophageal nerve ring and two pairs of longitudinal nerve cords, with the ventral pair innervating the foot and the dorsal pair forming a twist via streptoneury. The oesophageal nerve ring and pedal nerves are thickened and medullary in nature (Fig. 6b). There is no clear structural evidence from juvenile or adult specimen for the identification of specific ganglia (sensu Richter et al.
[28], i.e. nerve tissue in discrete units separated by an area containing no cell bodies), although the anterior region of the nervous system shows some intergressions of cell bodies into the central neuropil that appear to divide the mass into regions or lobes, the neural masses appear to be wholly fused and without ganglionic structure.

The anterior commissure, or frontal aspect of the oesophageal nerve ring, is large, connecting two lateral swellings (Fig. 5h). Laterally from each of these swellings is a large, prominent tentacular nerve projecting into the cephalic tentacles. There are no eyes and no evidence of even a remnant optic nerve emerging from the oesophageal nerve ring. At the posterior margin of the oesophageal nerve ring is a pair of prominent pleural swellings. From each pleural swelling a long nerve goes anteriorly along the margin of the mantle around the head.

Both the lateral (visceral) and pedal nerves, as well as a pair of mantle nerves, emerge from the posterior aspect of the oesophageal nerve ring more or less co-located in a large junction (Figs. 5f, 6b). The pedal nerves are fused in a large body and extend into two thick medullary cords, separating posteriorly into two clear cords (Fig. 6c) but joined at several points by bridging commissures. The pedal nerves are not embedded within the foot musculature but sit on the dorsal aspect of the foot muscle block, below the oesophageal gland mass (Fig. 7h). A number of branching nerves penetrate distally between muscle fibres into the muscle block of the foot, and the main pair of pedal nerves penetrate the ventral wall of the body cavity into the foot at the posterior (Figure $3 \mathrm{~b}$ ). A pair of statocysts are located medially, anterior of the pedal nerve cords, apparently innervated by them, more or less central in the animal body (Fig. 5h). The statocysts are surrounded by the oesophageal gland; each statocyst contains a single statolith (Fig. 6c).

The left lateral nerve cord is embedded within the oesophageal gland, passing underneath the intestinal loop and emerging at the right posterior, continuing to the nephridial tissue (Fig. 4c). The right lateral nerve cord crosses through the oesophageal gland above the left lateral nerve and emerges between the foregut and the hindgut underneath the gill. At this point a small nerve, positionally similar to the osphradial nerve in some other gastropods, splits from the main lateral nerve cord and runs anteriorly to the anterior mantle (Figs. $4 \mathrm{~b}, 5 \mathrm{f}$ ). The right lateral nerve posterior of this point continues above the digestive tract and below the gill and runs posteriorly to meet the terminus of the left lateral nerve cord.

A small pigmented patch is present at the right side of the gill stem at the anterior of the ctenidium; we tentatively compare this to the osphradium of other gastropods. This area could not been identified in the tomographic reconstruction of the juvenile specimen, and the putative osphradial nerve could not be seen in adult specimens. 

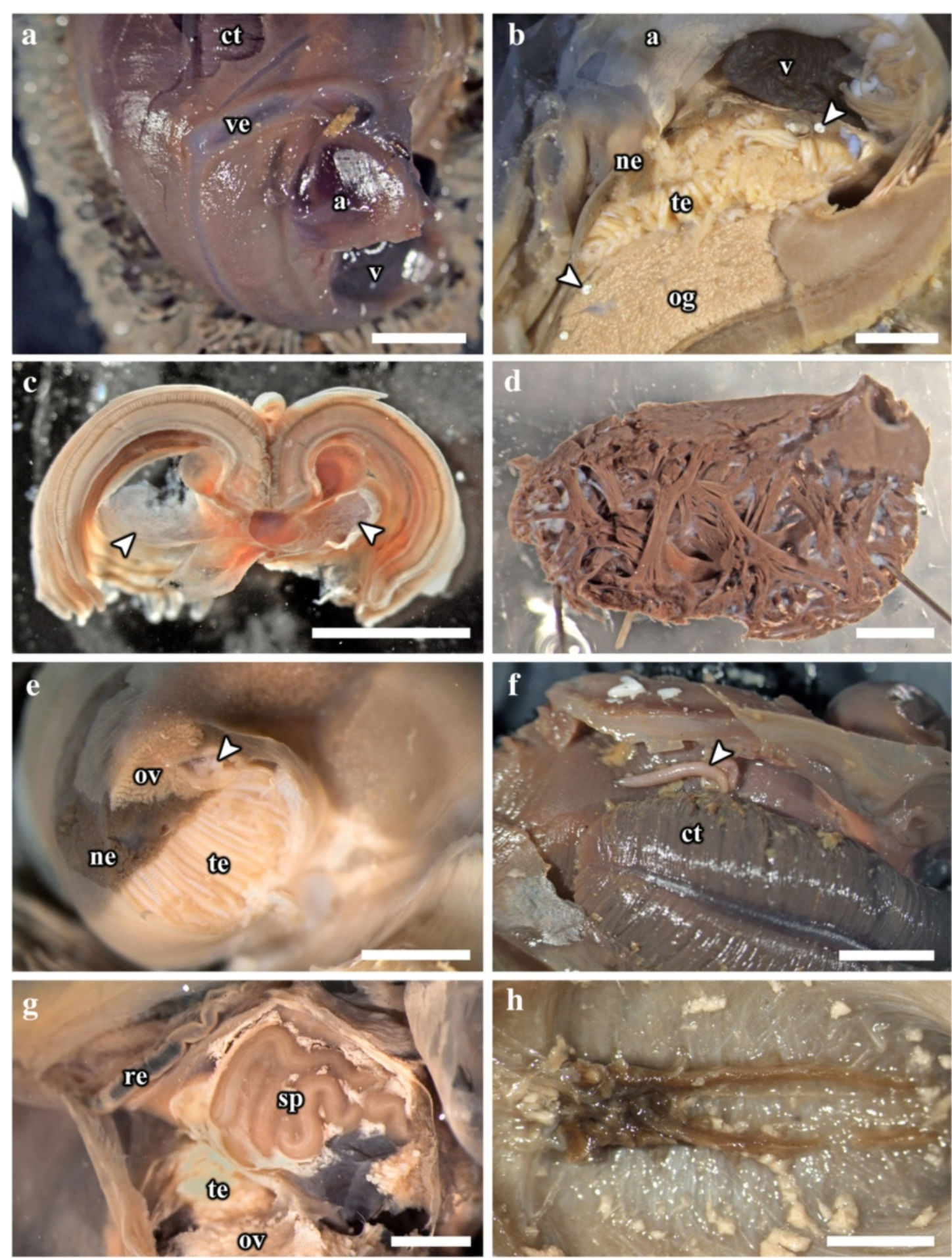

Fig. 7 (See legend on next page.) 
(See figure on previous page.)

Fig. 7 Photographs of the soft parts of adult Chrysomallon squamiferum. a. Dorsal view with shell and part of mantle removed, showing the ctenidium, heart, and associated blood vessels. b. Sagittal section; white arrows indicate sections of the hindgut showing white, chalky material inside. c. Transverse section through the ctenidium showing a pair of blood sinus (white arrows). $\mathbf{d}$. Sagittal section through ventricle showing muscle bundles. e. Transverse section of the visceral mass showing testis, ovary, and nephridium; white arrowhead indicates spermatophores inside the 'spermatophore producing organ'. f. Packaged spermatophore (white arrow). g. 'Spermatophore producing organ'. h. Pedal nerve cords, fused neural mass at anterior and numerous lateral offshoots distally into the foot. Abbreviations: a, auricle; ct, ctenidium; ne, nephridium; og, oesophageal gland; ov, ovary; re, rectum; sp, 'spermatophore producing organ'; te, testis; $v$, ventricle; ve, blood vessel. Scale bars: $a-c, e-f, h=5$ $\mathrm{mm}, \mathrm{d}, \mathrm{g}=2 \mathrm{~mm}$

We confirm the ctenidial bursicles observed by Warén et al. ([17]: fig. S2C) but could not identify these histologically from the juvenile specimen.

\section{Reproductive System}

Chrysomallon squamiferum is a simultaneous hermaphrodite. Adults possess both testis and ovary, although the level of development of the two varied in different individuals. The gonads are arranged as two discrete layers with the nephridial tissue between them, the testis to the ventral and the ovary dorsal (Fig. 7e).

A large organ is present on the distal body cavity on the right side of the animal as a distinct complex twisted duct fused into a disc distal of the testis, and this is associated with the male gonoduct, (Fig. $7 \mathrm{~g}$ ). We were not able to confirm spermatophores being packaged inside this organ (Fig. 7e). A packaged spermatophore was confirmed to be discharged from the gonopore of one individual (Fig. 7f), providing further evidence for internal fertilisation through transfer of spermatophore packets. Gonoducts from the testis and ovary are initially separate but apparently fuse to a single duct and emerge as a single genital opening on the right of the mantle cavity, ventral and anterior of the rectum (Fig. 1). This was also seen in the serially sectioned juvenile specimen (Fig. 6d), although this could not be traced as there was no mature gonad present, only putative proto-gonad found associated with the digestive gland (Fig. 6f). The genital opening in adults is simple, not associated with any specialised copulatory organs or appendages, and there are no penis modified from cephalic tentacles. In adults the gonads are displaced out of the shell apex into to the head-foot region at the right side (Fig. 1).

\section{Discussion}

Members of the gastropod clade Neomphalina are endemic to reducing environments in the deep sea, primarily living on hydrothermal vents (all Peltospiridae) but with some species on natural deposits of sunken wood [29]. The comprehensive anatomical framework presented in the present study allows us to consider both evidence for the phylogenetic affinity of Chrysomallon and also the nature of its particular anatomical characters.
Given the uniqueness of Chrysomallon's anatomy we suspect that this highly autapomorphic condition is the result of numerous adaptations associated with life in the acidic flow of hydrothermal vents. The anatomy of several other genera in Neomphalina has been described in detail through either dissection (e.g., [25]) or tomographic reconstruction [27]. The diversity of taxa with wellcharacterised anatomy encompasses Chrysomallon and members of all three families currently recognised in Neomphalina: in Peltospiridae mainly Rhynchopelta, Peltospira ([25]; also includes brief overview of Nodopelta, Echinopelta, and Hirtopelta), as well as Pachydermia [26]; in Neomphalidae Neomphalus [30] and Symmetromphalus [31]; in Melanodrymiidae Melanodrymia [32], Leptogyra, and Leptogyropsis ([27], with mentions of Xyleptogyra). The present study is the first to include both of these approaches to encompass comprehensive description across full post-settlement ontogeny.

The gross anatomy of Chrysomallon generally conforms to the neomphaline plan [27]. Warén et al. ([17]: fig. S2C) showed sensory bursicles on the tip of the gill filaments which are known to be present in most vetigastropods and present some neomphalines [27, 32], though the majority of taxa lack them (e.g., Pachyermia laevis [26]; Lirapex [33]). The lack of specialised copulatory organs in Chrysomallon conforms to Peltospiridae; members of the family Neomphalidae have the left cephalic tentacle modified as a penis $[25,31,34]$ and melanodrymiids have various special cephalic copulatory modifications [27, 32]. However, as a member of Peltospiridae, Chrysomallon is the only taxon in that family so far known to be a simultaneous hermaphrodite.

\section{Comparative anatomy}

The circulatory system of Chrysomallon is notably enlarged compared to other gastropods, as was briefly mentioned by Warén et al. [17]. On dissection, the blood sinuses and lumps of haemocoel material are a prominent feature throughout the body cavity. A cephalopedal haemocoel lined by a net of lacunae reported by Warén et al. [17] could not be found, but the blood sinuses are large and apparently mobile as they differ in position among individuals. The bipectinate 
ctenidium extends far behind the heart into the upper shell whorls, which is much larger compared to Peltospira with a similar shell shape and general form as well as other peltospirids $[25,26]$ or melanodrymiids $[27,32]$. It is similar, however, in proportional size to Hirtopelta which has the largest gill among peltospirid genera investigated anatomically so far $[25,35]$. An enlarged gill may be associated with filter-feeding (as is shown for neomphalid genera Neomphalus [30] and Symmetromphalus [31]), symbiotic bacteria on the gill (such as endosymbionts in Hirtopelta tufari Beck, 2002 [35] or Alviniconcha spp. provannids [36]), and/or high respiratory demand. There are no endosymbionts in the gill of Chrysomallon [22].

Given that Chrysomallon squamiferum hosts endosymbionts in the oesophageal gland, has no symbionts in or on the gill [22], and probably does not filter-feed, the most likely reason for enlargement of the gill is to fulfill raised respiratory needs. Nakagawa et al. [23] showed through whole-genome sequencing that the endosymbionts of C. squamiferum are thioautotrophic gammaproteobacteria with a full set of genes required for aerobic respiration, and probably capable of switching between more efficient aerobic respiration and less efficient anaerobic respiration depending on oxygen availability. The host also requires oxygen for survival, and the enlargement of gill is also likely to facilitate extracting oxygen from low oxygen conditions typical of hydrothermal vent ecosystems [1]. Being a coiled snail Chrysomallon is probably unable to increase respiratory surface area by increasing the mantle surface, as seen in many limpet form gastropods [37].

The most exceptional part of the circulatory system is the extremely large monotocardian heart, which has an especially well-developed ventricle with very thick muscular walls reinforced by muscle bundles running across the lumen. A ventricle with thick muscular wall is known in Peltospiridae from Rynchopelta concentrica [25], but the proportional size of heart is greater in Chrysomallon. In neomphalids the heart is not markedly muscular (Neomphalus, [30]). Unlike Pachydermia laevis where the auricle is larger than the ventricle [26], the ventricle is even larger than the auricle in Chrysomallon squamiferum. Large blood vessels dorsal and ventral to the ctenidium, together with numerous large blood sinuses under the gill and in the mantle cavity and the fact that the oesophageal gland is highly vascularised, indicate that the giant heart primarily serves the ctenidium and the oesophageal gland (also briefly noted by Warén et al. [17]).

The heart is unusually large for a peltospirid (compare to [25]) or indeed any animal proportionally. The heart of Chrysomallon is estimated at $4 \%$ of the body volume; by contrast the heart of a healthy human is averages at around $1.3 \%$ of the body volume (mean total heart volume of adult humans $778 \mathrm{ml}$, taken from [38]; mean human body volume $61.05 \mathrm{~L}$, average of both genders [39]). We interpret the heart, and particularly the muscular ventricle, functions to create suction that draws blood through the gill and thus pump haeomocoel to the rest of the circulatory system.

An oesophageal gland or pouch is a common feature in so-called basal gastropod clades, including Patelloidea, Vetigastropoda, Cocculiniformia, Neritimorpha and Neomphalina [40], but the extent of enlargement seen in Chrysomallon is orders of magnitude greater than any other gastropod anatomy described to date [17]. In other peltospirids, the posterior portion of the oesophagus forms a pair of blind mid-oesophageal pouches or gutters extending only to the anterior end of the foot (Rynchopelta, Peltospira, Nodopelta, Echinopelta, [25]: fig. 12; Pachydermia [26]; also Melanodrymia [32]). The oesophageal gland of Chrysomallon forms one single voluminous blind sac that extends much further posterior, to reach the heart. The oesophageal gland is known definitively to house one single strain of thioautotrophic endosymbiotic bacteria $[22,23]$. There are no other reports of oesophageal glands that are highly vascularized and containing blood sinuses as seen in Chrysomallon. Two families of limpet formed gastropods, Bathyphytophilidae and Lepetellidae, with members inhabiting chemosynthetic environments are also known to have enlarged oesophageal pouches, however, though not to the extent of Chrysomallon [41, 42]. Both are known to house endosymbiotic bacteria, in the case of bathyphytophilids most likely also in the oesophageal glands $[41,42]$ but in the lepetellids the endosymbionts are spread in the haemocoel [42]. The dominance of the greatly enlarged oesophageal gland housing endosymbiotic bacteria is in contrast with rest of the digestive system which is relatively small, suggesting that the endosymbionts are the key nutrient source. We further infer the function of the enlarged circulatory system and extremely high blood volume is relevant to the metabolism of the bacterial endosymbionts.

Most holobiont vent molluscs such as Calyptogena, Alviniconcha and Ifremeria house endosymbionts in the gill where bacteria can readily contact vent fluid through circulation in the mantle cavity $[1,36,43]$. In Calyptogena clams, for example, the bacteriocytes containing the endosymbionts are situated on the surface of gill filaments and have an absorptive end exposed to the mantle cavity. Vent fluid containing hydrogen sulfide is circulated in the mantle cavity and the endosymbionts simply take up the sulfide from this fluid $[1,44,45]$. In Chrysomallon, however, the endosymbionts are housed in oesophageal gland where they are isolated from the vent fluid. The host is thus likely to play a major role in supplying the endosymbionts with necessary chemicals 
leading to increased respiratory needs, similar to the scenario in the trophosome of Riftia pachyptila. To supply endosymbionts with sulfides, $R$. pachyptila takes in sulfides from the vent fluid through its plume and has hydrogen sulfide specific binding site on the haemoglobin molecule in the blood that transports sulfides to the trophosome [46]; such sulfide-specific binding site is lacking in the haemoglobin of Calyptogena [1, 44, 45]. The same may be happening with Chrysomallon and an elaborative cardiovascular system with a powerful heart is likely to help circulate sufficient oxygen or hydrogen sulfide through the blood stream, for the needs of the host (oxygen) and its symbiotic bacteria (oxygen and sulfide). Detailed investigation of the haemocoel of $C$. squamiferum will reveal further information regarding its oxygen carriers and if it has respiratory pigments that bind to sulfides or an alternative means of sulfide transport.

The stomach of Chrysomallon is similar in form to other neomphalines including the tubes we observed in the juvenile specimen that connect the stomach directly to the digestive gland ([30]: fig. 6). The intestine however is reduced [17] and only has a single loop, unlike grazing peltospirids [25, 26], most likely because of its nutritional reliance on endosymbiotic bacteria. Hirtopelta also has a reduced and narrow intestine [25], but members of that genus house endosymbionts on their enlarged gill filaments [35], and the intestinal reduction is likely to also be a result of convergence due to reliance on endosymbionts for nutrition. In filter-feeding neomphalids the intestine is also rather short (Neomphalus and Symmetromphalus); the gills of these are enlarged as well, but it is unknown if they house symbionts on the gill filaments. Melanodrimiids are detritivores and have longer intestines like grazing peltospirids [27, 32]. There is a general trend associating short simple guts with reliance on endosymbiosis rather than external nutrition through grazing.

Gut contents from C. squamiferum specimens did not include any coarse inorganic particles such as those commonly found ingested together with food by grazing or deposit feeding peltospirids such as Rhynchopelta concentrica [25]. Warén et al. [17] reported finely granular sulfides from the gut of $C$. squamiferum and suggested that these likely originated from the endosymbionts; we also confirmed these sulfides. The material nature of the predominant chalky material in the posterior region of the gut is still unclear. The chalky gut content may represent ingested endosymbionts or other food source (such as filter-feeding), it is currently unclear whether this species has other mechanisms of feeding.

The radula of C. squamiferum is proportionately much larger in juveniles compared with adults. The animals could feed by grazing as juveniles; there is also a putative shift in diet reported from Neomphalus where juveniles feed by grazing and shift to exclusive filter-feeding in later life [30]. However the material in the gut of the serially-sectioned juvenile $C$. squamiferum contained similar material to the adult guts, the foregut of the juvenile was also empty and the oesophageal gland was proportionately as large in the juvenile as in adults. This suggests C. squamiferum likely relies on endosymbionts for nutrition throughout its entire post-larval life. The endosymbionts are remarkably similar in their genome with only two synonymous changes in 19 genes and 13810 codon positions, across 32 host individuals [23]. Nakagawa et al. [23] suggested this is a result of stringent selection of horizontally transferred endosymbiont by the host.

No other neomphalines are known to have endosymbionts housed in the oesophageal gland, although Hirtopelta tufari is known to house endosymbionts in the ctenidium (Beck, 2002) in a similar association as found in provannid gastropod species in Alviniconcha and Ifremeria [29]. Another undescribed peltospirid from Antarctic vents at East Scotia Ridge of similar body size to C. squamiferum ('Peltospiroid n. sp. ESR', [47]) has been shown through stable isotope analyses to possibly be reliant on endosymbionts for nutrition [48].

The single nephridium in C. squamiferum is displaced to the right of the body, similar to the structure seen in Hirtopelta ([25]: fig. 15). This may be attributable to the enlarged gill taking up the entire left side of mantle cavity, seen in both taxa. The left side of the body in $C$. squamiferum has numerous voluminous blood sinuses that occupy all available space.

The arrangement of the nervous system in C. squamiferum is reduced in complexity and enlarged in size compared to other neomphaline taxa. The lateral swellings of the oesophageal nerve ring, emitting the tentacular nerves, may represent a homologous region to cerebral ganglia in other gastropods; however, their forward placement relative to the origin of the lateral nerve cords confounds positional homology. The cerebral ganglia emit the lateral nerve cords in molluscan tetraneury [49] but in C. squamiferum there is a large multi-way junction at the posterior margin of the oesophageal nerve ring that seems to represent a fusion of the typical molluscan ganglia. The medullary nature of the major nerve cords and the enlarged anterior commissure (incorporating the 'cerebral' lateral swellings) is reminiscent of the nervous system of Polyplacophora [50].

The single statolith in the pair of statocysts is the same condition as for all other reported instances in Neomphalina [27]. There is a distinct nerve extending to the anterior mantle, positionally equivalent to the nerve extending forward from the osphradial ganglion particularly in Leptogyra [27]. The 'osphradium' was described as located on the shell muscle in Rhychopelta [25], but on the gill stem in Pachydermia [26] and in Chrysomallon. This level of variability is typical among molluscs 
and the function (if any) of these structures is entirely speculative [51].

The simultaneous hermaphrodite condition in C. squamiferum is so far unique among Peltospiridae $[25,29,52]$ and paralleled only among Neomphalina by Leptogyra in Melanodrymiidae (known definitively for L. constricta Marshall, 1988 and L. patula Marshall, 1988; [27]). Early observations suggesting separate males and females in C. squamiferum [17] were probably a result of variation in the relative development of the two gonads in different individuals. At the time of the first discovery and report of C. squamiferum all known neomphalines (i.e. then excluding Leptogyra) had separate sexes.

Chrysomallon squamiferum also does not have any specialised copulatory organs on the head, which is consistent with other peltospirids [25, 26]. In Melanodrymiidae, Leptogyra hermaphrodites have a penis and accessory penis extending from the base of the left cephalic tentacle. All other three melanodrymiid genera have separate sexes and males have copulatory organs $[27,32,53]$. All four genera in family Neomphalidae with available information have separate sexes and the left cephalic tentacle in males is modified into a penis (also Retiskenea but the familial placement of this genus is uncertain) $[27,33]$.

Both gonads in Leptogyra share a single gonoduct with the ovary positioned anterior of the testis and the species maybe protandric [32]; by contrast the gonads in C. squamiferum are clearly simultaneously present in vertical stacking and two gonoducts appear to fuse into a single genital opening. We have observed the structure previously reported as a 'spermatophore producing organ' [17]; however, we note that it is similar in position and structure to the seminal receptical illustrated in Leptogyra [27]. Previously, spermatophores in Neomphalina were known from other taxa in Peltospiridae (Pachydermia laevis; [17]) and also Melanodrymiidae (Melanodrymia; [33]) but not from Neomphalidae.

The selection process leading to the convergent evolution of limpet-form from spirally coiled ancestors has occurred repeatedly among Gastropoda [54, 55]. Shifting from a coiled form to a limpet form has impacts on the positions of organ systems, in particular the relative positions of gonads and digestive gland [56]. In gastropods, the gonad can either be located to the extreme posterior, near the shell apex (the norm for species with a coiled shell) or in an opposite arrangement with the digestive glands at the apex and gonads anterior of it (the norm for limpets) [56]. In $C$. squamiferum, the digestive gland occupies the apex and gonads are displaced anteriorly, and this has previously been attributed to a morphological shift toward the limpet form [17]. Among other Peltospiridae, the anterior gonad is observed in the coiled Peltospira and Chrysomallon, as well as limpet-formed species (e.g., Rhynchopelta, Echinopelta
[25]); but some, such as Hirtopelta, have the opposite arrangement ([25]: fig. 15). Neomphalina as a clade is extremely variable in shell forms ([29]: fig. 7.6). Hence another possible interpretation is that Chrysomallon may be secondarily coiled derivation from a recent limpet-form ancestor. Gonad position is, unfortunately, apparently not particularly informative for phylogenetic inference.

Vent invertebrates exhibit a wide range of reproductive traits but tend to have high dispersal ability associated with rapid growth and continuous reproduction [57-59]. Individual hydrothermal vent fields are generally ephemeral and patchy in distribution and vent-endemic invertebrate species must maintain a viable metapopulation across many vent fields to persist and prosper [60, 61] . The patchiness of many deep-sea habitats also means that the chances of larvae successfully colonising a suitable habitat may be low $[61,62]$. Displacing the gonads out of the coiled shell apex and into the body whorl provides a larger volume of space for gonads to develop; this may have advantages for C. squamiferum in increasing fecundity and in turn increasing the chance of its larvae arriving at a different vent field. Additional inference of gonad index and reproductive quality and fecundity could be determined anatomically [63-66], although we have not attempted this within the present study. Chrysomallon squamiferum is presumed to have lecithotrophic larvae with a planktonic dispersal stage like other neomphalines [67], but further aspects of larval dispersal, behaviour, survivability, and metamorphosis are so far largely intractable in deep-sea ecosystems because of the inaccessibility of the living organisms.

\section{Adaptive significance}

This study illustrates how the perception of an organism can be enhanced and fundamentally changed by understanding its internal anatomy. Metazoans in hydrothermal vent environments depend on morphological and physiological adaptations to resolve energetic needs in a food chain based on chemoautotrophy [1, 5, 6, 44]. In this case, we speculate that the derived strategy of housing endosymbiotic microbes in a greatly enlarged oesophageal gland, has been the catalyst for anatomical innovations that serve primarily to improve the fitness of the bacteria, over and above the needs of the metazoan host.

Chrysomallon squamiferum lives adjacent to acidic and reducing vent fluid from black smokers or diffuse venting, which contain the chemical and substrates required by the chemoautotrophic bacteria [12, 18, 22]. Chrysomallon squamiferum differs distinctly from other deep-sea gastropods, even closely-related neomphalines. The unique external armature of hard dermal sclerites, which are often biomineralised with iron sulfide [19, 20], may help protect the gastropod from the vent fluid, so 
that its bacteria can live close to the source of electron donors for chemosynthesis. Alternatively, the sclerites may result from deposition of toxic sulfide waste from the endosymbionts, and therefore represent a novel solution for detoxification.

The digestive system of Chrysomallon is simple and reduced as nutrition is mainly provided by the endosymbionts, and may be processing solid waste perhaps accidentally ingested. The circulatory system has a huge blood volume and a muscular ventricle that draws blood from the elaborate gill to supply the bacteria. With the significant additional embranchment of the circulatory system in the form of fine blood sinuses within the oesophageal gland, the blood pressure likely decreases to almost zero. The giant 'dragon heart' may therefore be necessary to maintain haemocoel circulation throughout the body and particularly the fine blood vessels serving the oesophageal gland where the endosymbionts are housed. This gastropod has no brain, the huge fused neural mass is directly adjacent to and passes through the oesophageal gland where the bacteria are housed. The reproductive system is displaced anteriorly, perhaps enabling greater fecundity. In sum, this dramatic 'dragon-like' animal has become a carrying vessel for the survival and propagation of its bacterial endosymbionts.

\section{Materials and methods}

All specimens examined herein were collected from the Longqi vent field [16] (also known as Dragon vent field $[13,14])$, Southwest Indian Ridge, 37 $47.03^{\prime} \mathrm{S} 49^{\circ} 38.97^{\prime} \mathrm{E}$ ('Tiamat Chimney'), depth $2785 \mathrm{~m}$, on-board RRS James Cook expedition JC67 using the suction sampler of the remotely operated vehicle (ROV) Kiel 6000 [13]. Chrysomallon squamiferum was densely populated in the areas immediately surrounding diffuse-flow venting, seen visually as shimmering water. The specimens were fixed and stored in $4 \%$ buffered formalin upon retrieval on-board the ship.

10 adult specimens were dissected with the aid of stereo microscopes (Olympus SZX9, SZX16) and photographs were taken using a digital single lens reflex (DSLR) camera (Olympus E-600) mounted to the microscope trinocular.

One specimen with shell and mantle removed was freeze-dried overnight and Scanning Electron Microscopy (SEM) was undertaken using a Hitachi TM3000 table-top SEM (British Antarctic Survey, Cambridge), to capture the structural details of head and ctenidium. As the specimen was large 22 micrographs were stacked in the software Adobe Photoshop CS4 to compose the final image.

One of the smallest C. squamiferum juvenile specimens ever collected (shell length ca. $3 \mathrm{~mm}$ ) was selected for serial sectioning and 3D tomographic reconstruction.
The selected juvenile specimen was decalcified in $2 \%$ EDTA ( $\mathrm{pH}$ 7.2) for 48 hours, followed by subsequent acetone dehydration series, embedding, and tomographic model reconstruction using the software AMIRA v.5.3.3 (FEI Visualisation Sciences Group) as described by Ruthensteiner [68].

Prior to embedding, the specimen was stored in diluted Epon epoxy resin mixture (1:1 with $100 \%$ acetone) overnight at room temperature unlidded, allowing acetone to evaporate. The specimen was then embedded in Epon with DPM-30 accelerator for a further 24 hours at $60{ }^{\circ} \mathrm{C}$, according to the manufacturer's instructions (Sigma). Samples were serially sectioned at a thickness of $1.5 \mu \mathrm{m}$ using an automated rotary microtome (Leica RM2255) fitted with a diamond knife (HistoJumbo $8 \mathrm{~mm}$, DiATOME, Switzerland). Sections were stained using the high contrast monochromatic methylene blue-azure II stain [69] and cover-slipped using Araldite resin following manufacturer's instructions (Agar Scientific).

The serial semithin sections of the complete animal included 1700 sections; a subsample of every third section throughout the entire specimen was digitally captured using a DSLR camera (Olympus E-600) mounted to a compound microscope trinocular (Olympus BX41), at an appropriate magnification to maximise specimen visibility. The resulting images were processed in Adobe Photoshop CS4 for contrast enhancement, size reduction, and converted to greyscale. The processed images were imported into Amira v5.3.3 and aligned into a single stack. Materials of interest were highlighted digitally throughout the stack for 3D visualisation and the final tomographic model was produced by post-processing including surface rendering and smoothing. The resulting semithin sections are deposited in Zoologische Staatssammlung München (Munich, Germany), with catalogue number ZSM 20151000.

\section{Additional file}

Additional file 1: Figure S1. 3D tomographic reconstruction of the 'scaly-foot gatropod', Chrysomallon squamiferum, as a full interactive model. The model can be accessed by clicking into the figure (Adobe Acrobat Reader v7 or higher). Left click and drag to rotate, hold down the 'control' key while doing so to move, and hold down 'shift' to zoom. The dropdown menu in the floating window or the view pane in the model tree can be used to switch between pre-saved views.

Components can also be activated or de-activated by toggling the checkbox in the model tree. The 3D PDF was generated using Adobe Acrobat Pro XI by importing .u3d files, converted from .obj exports of AMIRA v5.3.3 surface files.

Competing interests

The authors declare that they have no competing interests.

\section{Authors' contributions}

CC and JDS conceived the study, and conducted all laboratory work and analysis. JTC, ADR, and CC contributed to collecting the original specimens. 
$\mathrm{KL}$ assisted with the interpretation of data. CC drafted the manuscript, all authors contributed to and approved the final manuscript.

\section{Acknowledgements}

Lauren Sumner-Looney (Queen's University Belfast) is gratefully acknowledged for her great help in the laboratory work and 3D modelling, as well as stimulating discussions. We also thank Dr John Grahame (University of Leeds) and many other colleagues who contributed further valuable discussions to the project. This research was supported by a Research Grant from the Malacological Society of London to CC. We owe a great deal to the Master and crew of the RRS James Cook, as well as pilots and technical teams of ROV Kiel 6000 for their tremendous support of the scientific activities during the cruises JC66/67 funded by NERC Small Research Grant NE/H012087/1 to JTC and NERC Research Grant NE/F005504/1 to ADR. We are grateful for the logistics and shipboard support provided by the staffs of the UK National Marine Facilities at the National Oceanography Centre, Southampton. Prof. Gerhard Haszprunar and two anonymous referees greatly improved an earlier version of this paper.

\section{Author details}

${ }^{1}$ Department of Zoology, University of Oxford, The Tinbergen Building, South Parks Road, Oxford OX1 3PS, UK. ${ }^{2}$ Ocean and Earth Science, University of Southampton, European Way, Southampton SO14 3ZH, UK. ${ }^{3}$ British Antarctic Survey, High Cross, Cambridge CB3 OET, UK. ${ }^{4}$ Queen's University Belfast, Marine Laboratory, Portaferry BT22 1PF, Northern Ireland.

Received: 23 February 2015 Accepted: 15 May 2015 Published online: 18 June 2015

\section{References}

1. Van Dover CL. The Ecology of Deep-Sea Hydrothermal Vents. Princeton: Princeton University Press; 2000.

2. Hourdez S, Lallier F. Adaptations to hypoxia in hydrothermal-vent and cold-seep invertebrates. In: Amils R, Ellis-Evans C, Hinghofer-Szalkay H, editors. Life in Extreme Environments. Springer Netherlands; 2007:297-313 http://link.springer.com/chapter/10.1007\%2F978-1-4020-6285-8_19.

3. Fisher CR. Ecophysiology of primary production at deep-sea vents and seeps. In: Uiblein F, Ott J, Stachowtisch M, editors. Deep-sea and Extreme Shallow-water Habitats: Affinities and Adaptations. Biosyst Ecol Ser, vol 11. Vienna: Österreichische Akademie der Wissenschaften; 1996:313-36

4. Petersen JM, Ramette A, Lott C, Cambon-Bonavita M-A, Zbinden M, Dubilier N. Dual symbiosis of the vent shrimp Rimicaris exoculata with filamentous gamma- and epsilonproteobacteria at four Mid-Atlantic Ridge hydrothermal vent fields. Environ Microbiol. 2010;12(8):2204-18.

5. Watsuji T-O, Yamamoto A, Motoki K, Ueda K, Hada E, Takaki Y et al. Molecular evidence of digestion and absorption of epibiotic bacterial community by deep-sea crab Shinkaia crosnieri. ISME J 2014.

6. Cavanaugh CM, Gardiner SL, Jones ML, Jannasch HW, Waterbury JB. Prokaryotic cells in the hydrothermal vent tube worm Riftia pachyptila Jones: possible chemoautotrophic symbionts. Science. 1981;213:340-2.

7. Kim YW, Yasuda M, Yamagishi A, Oshima T, Ohta S. Characterization of the endosymbiont of a deep-sea bivalve Calyptogena soyoae. Appl Environ Microb. 1995;61(2):823-7.

8. Page HM, Fiala-Medioni A, Fisher CR, Childress JJ. Experimental evidence for filter-feeding by the hydrothermal vent mussel Bathymodiolus thermophilus. Deep-Sea Res Pt A. 1991;38(12):1455-61.

9. Jouin C, Gaill F. Gills of hydrothermal vent annelids: structure, ultrastructure and functional implications in two alvinellid species. Prog Oceanogr. 1990;24(1-4):59-69.

10. Andersen AC, Jolivet S, Claudinot S, Lallier FH. Biometry of the branchial plume in the hydrothermal vent tubeworm Riftia pachyptila (Vestimentifera; Annelida). Can J Zoolog. 2002;80(2):320-32.

11. Chen C, Linse K, Copley JT, Rogers AD. The 'scaly-foot gastropod': a new genus and species of hydrothermal vent-endemic gastropod (Neomphalina: Peltospiridae) from the Indian Ocean. Journal of Molluscan Studies 2015, Advance Access published April 20, 2015, doi:10.1093/mollus/eyv013

12. van Dover CL, Humphris SE, Fornari D, Cavanaugh CM, Collier R, Goffredi SK, et al. Biogeography and ecological setting of Indian Ocean hydrothermal vents. Science. 2001;294(5543):818-23.

13. Copley JT. Research cruise JC67, Dragon vent field, SW Indian Ocean, 27-30 November 2011. RRS James Cook cruise report. British Oceanographic Data
Centre; 2011: Available from http://www.bodc.ac.uk/data/information_and_ inventories/cruise_inventory/report/10593/

14. Roterman CN, Copley JT, Linse KT, Tyler PA, Rogers AD. The biogeography of the yeti crabs (Kiwaidae) with notes on the phylogeny of the Chirostyloidea (Decapoda: Anomura). Proc R Soc B. 2013;280(1764):20130718.

15. Tao C, Lin J, Guo S, Chen YJ, Wu G, Han X, et al. First active hydrothermal vents on an ultraslow-spreading center: Southwest Indian Ridge. Geology. 2012;40(1):47-50.

16. Tao C, Li H, Jin X, Zhou J, Wu T, He Y, et al. Seafloor hydrothermal activity and polymetallic sulfide exploration on the Southwest Indian Ridge. Chinese Sci Bull 2014:1-11

17. Warén A, Bengtson S, Goffredi SK, Van Dover CL. A hot-vent gastropod with iron sulfide dermal sclerites. Science. 2003;302(5647):1007.

18. Nakamura K, Watanabe H, Miyazaki J, Takai K, Kawagucci S, Noguchi T, et al. Discovery of new hydrothermal activity and chemosynthetic fauna on the Central Indian Ridge at $18^{\circ}-20^{\circ}$ S. PLoS One. 2012;7(3), e32965.

19. Chen C, Copley JT, Linse K, Rogers AD, Sigwart J. How the mollusc got its scales: convergent evolution of the molluscan scleritome. Biol J Linn Soc 2015: doi: 10.1111/bij.12462

20. Suzuki Y, Kopp RE, Kogure T, Suga A, Takai K, Tsuchida S, et al. Sclerite formation in the hydrothermal-vent 'scaly-foot gastropod': Possible control of iron sulfide biomineralization by the animal. Earth Planet Sc Lett. 2006;242:39-50.

21. Yao H, Dao M, Imholt T, Huang J, Wheeler K, Bonilla A, et al. Protection mechanisms of the iron-plated armor of a deep-sea hydrothermal vent gastropod. Proc Natl Acad Sci U S A. 2010;107(3):987-92.

22. Goffredi SK, Warén A, Orphan VJ, van Dover CL, Vrijenhoek RC. Novel forms of structural integration between microbes and a hydrothermal vent gastropod from the Indian Ocean. Appl Environ Microb. 2004;70(5):3082-90.

23. Nakagawa S, Shimamura S, Takaki Y, Suzuki Y, Murakami S-i, Watanabe T, et al. Allying with armored snails: the complete genome of gammaproteobacterial endosymbiont. ISME J. 2014;8(1):40-51.

24. Beinart RA, Sanders JG, Faure B, Sylva SP, Lee RW, Becker EL, et al. Evidence for the role of endosymbionts in regional-scale habitat partitioning by hydrothermal vent symbioses. Proc Natl Acad Sci U S A. 2012;109(47):E3241-E50.

25. Fretter $\mathrm{V}$. The anatomy of some new archaeogastropod limpets (Superfamily Peltospiracea) from hydrothermal vents. J Zool. 1989;218(1):123-69.

26. Israelsson $\mathrm{O}$. The anatomy of Pachydermia laevis (Archaeogastropoda: 'Peltospiridae'). J Moll Stud. 1998;64(1):93-109.

27. Heß M, Beck F, Gensler H, Kano Y, Kiel S, Haszprunar G. Microanatomy, shell structre and molecular phylogeny of Leptogyra, Xyleptogyra and Leptogyropsis (Gastropoda: Neomphalida: Melanodrymiidae) from sunken wood. J Moll Stud. 2008;74(4):383-401.

28. Richter S, Loesel R, Purschke G, Schmidt-Rhaesa A, Scholtz G, Stach T, et al. Invertebrate neurophylogeny: suggested terms and definitions for a neuroanatomical glossary. Front Zool. 2010;7(1):29.

29. Sasaki T, Warén A, Kano Y, Okutani T, Fujikura K, Kiel S. Gastropods from recent hot vents and cold seeps: systematics, diversity and life strategies. In: Kiel S, editor. The Vent and Seep Biota. Topics in Geobiology. Netherlands: Springer 2010:169-254.

30. Fretter V, Graham A, McLean J. The anatomy of the galapagos rift limpet Neomphalus fretterae. Malacologia. 1981;21(1-2):337-61.

31. Beck LA. Symmetromphalus hageni sp. n., a new neomphalid gastropod (Prosobranchia: Neomphalidae) from hydrothermal vents at the Manus Back-Arc Basin (Bismarck Sea, Papua New Guinea). Ann Nat Hist Mus Wien Ser B Bot Zool. 1992;92B:277-87.

32. Haszprunar G. The anatomy of Melanodrymia aurantiaca Hickman, a coiled Archaeogastropod from the East Pacific hydrothermal vents (Mollusca, Gastropoda). Acta Zool. 1989;70(3):175-86.

33. Warén A, Bouchet P. Gastropoda and Monoplacophora from hydrothermal vents and seeps: New taxa and records. The Veliger. 2001;44.

34. Warén A, Bouchet P. New gastropods from East Pacific hydrothermal vents Zool Scr. 1989;18(1):67-102.

35. Beck LA. Hirtopelta tufari sp. n., a new gastropod species from hot vents at the East Pacific Rise $\left(21^{\circ} \mathrm{S}\right)$ harbouring endocytosymbiotic bacteria in its gill (Gastropoda: Rhipidoglossa: Peltospiridae). Arch Molluskenkd. 2002;130:249-57.

36. Stein JL, Cary SC, Hessler RR, Ohta S, Vetter RD, Childress JJ, et al. Chemoautotrophic symbiosis in a hydrothermal vent gastropod. Biol Bull. 1988;174(3):373-8. 
37. Lindberg DR, Ponder WF. The influence of classification on the evolutionary interpretation of structure a re-evaluation of the evolution of the pallial cavity of gastropod molluscs. Organisms Diversity \& Evolution. 2001;1 (4):273-99.

38. Carlsson M, Cain P, Holmqvist C, Stahlberg F, Lundback S, Arheden H. Total heart volume variation throughout the cardiac cycle in humans. Am J Physiol Heart Circ Physiol. 2004;287(1):H243-H50.

39. Sendroy JJ, Collison HA. Determination of human body volume from height and weight. J Appl Physiol. 1965;21(1):167-72.

40. Sasaki T. Comparative anatomy and phylogeny of the recent Archaeogastropoda (Mollusca: Gastropoda). Univ Mus Tokyo Bull. 1998;38:1-224.

41. Haszprunar G, McLean JH. Anatomy and systematics of bathyphytophilid limpets (Mollusca, Archaeogastropoda) from the northeastern Pacific. Zool Scr. 1996;25(1):35-49.

42. Judge J, Haszprunar G. The anatomy of Lepetella sierrai (Vetigastropoda, Lepetelloidea): implications for reproduction, feeding, and symbiosis in lepetellid limpets. Invertebr Biol. 2014;133(4):324-39.

43. Suzuki $Y$, Sasaki T, Suzuki M, Nogi Y, Miwa T, Takai $K$, et al. Novel chemoautotrophic endosymbiosis between a member of the Epsilonproteobacteria and the hydrothermal-vent gastropod Alviniconcha aff. hessleri (Gastropoda: Provannidae) from the Indian Ocean. Appl Environ Microb. 2005;71(9):5440-50.

44. Fiala-Médioni A, Le Pennec M. Trophic structural adaptations in relation to the bacterial associations of bivalve molluscs from hydrothermal vents and subduction zones. Symbiosis. 1987;4:63-74.

45. Fiala-Médioni A, Le Pennec M. Structural adaptations in the gill of the japanese subduction zone bivalves (vesicomyidae) Calyptogena phaseoliformis and Calyptogena laubieri. Oceanol Acta. 1988;11(2):185-92.

46. Arp AJ, Childress JJ, Vetter RD. The sulphide-binding protein in the blood of the vestimentiferan tube-worm, Riftia pachyptila, is the extracellular haemoglobin. J Exp Biol. 1987;128(1):139-58.

47. Rogers AD, Tyler PA, Connelly DP, Copley JT, James R, Larter RD, et al. The discovery of new deep-sea hydrothermal vent communities in the Southern Ocean and implications for biogeography. PLOS Biol. 2012;10(1), e1001234

48. Reid WDK, Sweeting CJ, Wigham BD, Zwirglmaier K, Hawkes JA, McGill RAR, et al. Spatial differences in East Scotia Ridge hydrothermal vent food webs: influences of chemistry, microbiology and predation on trophodynamics. PLoS One. 2013;8(6):e65553.

49. Sigwart JD, Sumner-Rooney LH. Mollusca: Caudofoveata, Monoplacophora, Polyplacophora, Scaphopoda, Solenogastres. In: Schmidt-Rhaesa A, Harzsch S, Purschke G, editors. Structure and Evolution of Invertebrate Nervous Systems. Oxford, UK: Oxford University Press; in press.

50. Sigwart JD, Sumner-Rooney LH, Schwabe E, Heß M, Brennan GP, Schrödl M. A new sensory organ in "primitive" molluscs (Polyplacophora: Lepidopleurida), and its context in the nervous system of chitons. Front Zool. 2014;11(1):7.

51. Lindberg DR, Sigwart JD. What is the molluscan osphradium? An evaluation of homology. Zool Anz in press.

52. Tyler PA, Pendlebury S, Mills SW, Mullineaux L, Eckelbarger KJ, Baker M, et al. Reproduction of gastropods from vents on the East Pacific Rise and the Mid-Atlantic Ridge. J Shellfish Res. 2008;27(1):107-18.

53. Marshall BA. Skeneidae, Vitrinellidae and Orbitestellidae (Mollusca: Gastropoda) associated with biogenic substrata from bathyal depth off New Zealand and New South Wales. J Nat Hist. 1988;22:949-1004.

54. Ponder WF, Lindberg DR. Towards a phylogeny of gastropod molluscs: an analysis using morphological characters. Zool J Linn Soc. 1997;119(2):83-265.

55. Ponder WF, Lindberg DR. Phylogeny and Evolution of the Mollusca. Oakland, California, USA: University of California Press; 2008.

56. Fretter V, Graham A. British Prosobranch Molluscs: Their Functional Anatomy and Ecology (Revised Edition). Ray Society: London, UK; 1994.

57. Desbruyères $D$, Laubier $L$. Primary consumers from hydrothermal vents animal communities. In: Rona P, Boström K, Laubier L, Smith Jr K, editors. Hydrothermal Processes at Seafloor Spreading Centers. NATO Conference Series: Springer US; 1983. p. 711-34.

58. Adams DK, Arellano SM, Govenar B. Larval dispersal: vent life in the water column. Oceanography. 2012;25:256-68.

59. Nakamura M, Chen C, Mitarai S. Insights into life-history traits of Munidopsis spp. (Anomura: Munidopsidae) from hydrothermal vent fields in the Okinawa Trough, in comparison with the existing data. Deep-Sea Res Pt I. 2015;100:48-53.
60. Vrijenhoek R. Gene flow and genetic diversity in naturally fragmented metapopulations of deep-sea hydrothermal vent animals. J Hered. 1997:88(4):285-93.

61. Vrijenhoek RC. Genetic diversity and connectivity of deep-sea hydrothermal vent metapopulations. Mol Ecol. 2010;19(20):4391-411.

62. Yearsley JM, Sigwart JD. Larval transport modeling of deep-sea invertebrates can aid the search for undiscovered populations. PLoS One. 2011;6(8), e23063.

63. Nakamura M, Watanabe H, Sasaki T, Ishibashi J, Fujikura K, Mitarai S. Life history traits of Lepetodrilus nux in the Okinawa Trough, based upon gametogenesis, shell size, and genetic variability. Mar Ecol Prog Ser. 2014;505:119-30

64. Tyler P, Young C. Reproduction and dispersal at vents and cold seeps. J Mar Biol Assoc UK. 1999;79(2):193-208.

65. Young CM. Reproduction, development and life-history traits. In: Tyler PA, editor. Ecosystems of the World. Rotterdam, the Netherlands: Elsevier; 2003:381-426

66. Nye V, Copley JT, Tyler PA. Spatial variation in the population structure and reproductive biology of Rimicaris hybisae (Caridea: Alvinocarididae) at hydrothermal vents on the Mid-Cayman Spreading Centre. PLoS One. 2013;8(3), e60319.

67. Warén A, Bouchet P, Cosel RV. Mollusca, Gastropoda. In: Desbruyères D, Segonzac M, Bright M, editors. Denisia. 2 ed. Handbook of Deep-Sea Hydrothermal Vent Fauna (2nd edition). Zurich, Switzerland: Swiss National Museum; 2006:82-137.

68. Ruthensteiner B, Heß M. Embedding 3D models of biological specimens in PDF publications. Microsc Res Techniq. 2008;71(11):778-86.

69. Richardson $\mathrm{KC}$, Jarett $\mathrm{L}$, Finke $\mathrm{EH}$. Embedding in epoxy resins for ultrathin sectioning in electron microscopy. Stain Technol. 1960;35:313-23.

\section{Submit your next manuscript to BioMed Central and take full advantage of:}

- Convenient online submission

- Thorough peer review

- No space constraints or color figure charges

- Immediate publication on acceptance

- Inclusion in PubMed, CAS, Scopus and Google Scholar

- Research which is freely available for redistribution 